Santa Clara University

Scholar Commons

Operations Management \& Information Systems

Leavey School of Business

$12-2015$

\title{
Determinants of vendor profitability in two contractual regimes: an empirical analysis of enterprise resource planning projects
}

Stefan Hoermann

Tobias Hlavka

Michael Schermann

Santa Clara University, mschermann@scu.edu

Helmut Krcmar

Follow this and additional works at: http://scholarcommons.scu.edu/omis

Part of the Management Information Systems Commons

\section{Recommended Citation}

Hoermann, S., Hlavka, T., Schermann, M., and Krcmar, H. (2015): "Determinants of Vendor Profitability in Two Contractual Regimes: An Empirical Analysis of Enterprise Resource Planning Projects", Journal of Information Technology (30:4), 325-336.

This is a post-peer-review, pre-copyedit version of an article published in Journal of Information Technology. The definitive publisher-authenticated version Hoermann, Stefan, Tobias Hlavka, Michael Schermann, and Helmut Krcmar. "Determinants of Vendor Profitability in Two Contractual Regimes: An Empirical Analysis of Enterprise Resource Planning Projects." J Inf Technol Journal of Information Technology 30.4 (2014): $325-36$ is available online at: http://doi.org/10.1057/jit.2014.13

This Article is brought to you for free and open access by the Leavey School of Business at Scholar Commons. It has been accepted for inclusion in Operations Management \& Information Systems by an authorized administrator of Scholar Commons. For more information, please contact rscroggin@scu.edu. 


\section{Determinants of vendor profitability in two contractual regimes: An empirical analysis of enterprise resource planning projects}

Hoermann, Stefan

Technische Universität München

Chair for Information Systems

Boltzmannstraße 3

85748 Garching, Germany

+498928919546

stefan.hoermann@in.tum.de

Hlavka, Tobias

Technische Universität München

Chair for Information Systems

Boltzmannstraße 3

85748 Garching, Germany

tobias.hlavka@in.tum.de

Schermann, Michael (corresponding author)

Technische Universität München

Chair for Information Systems

Boltzmannstraße 3

85748 Garching, Germany

michael.schermann@in.tum.de

Prof. Dr. Krcmar, Helmut

Technische Universität München

Chair for Information Systems

Boltzmannstraße 3

85748 Garching, Germany

krcmar@in.tum.de

Running title: Determinants of vendor profitability

Acknowledgements: Support for this project was provided by the German Research Foundation (DFG SCHE 1805). Support for this research was provided by the Technische Universität München (TUM) Graduate School and the TUM Center for Doctoral Studies in Informatics and its Applications (CeDoSiA). The authors would like to thank Carol Krcmar for editorial assistance. 


\title{
Determinants of vendor profitability in two contractual regimes: An empirical analysis of enterprise resource planning (ERP) outsourcing projects
}

\begin{abstract}
In this paper, we investigate the effects of four determinants of vendor profitability in enterprise resource planning (ERP) outsourcing projects under two contractual regimes: fixed price (FP) contracts and time and material (TM) contracts. We hypothesize that effect sizes are larger under FP contracts than under TM contracts. From a transaction cost economics perspective, we hypothesize that project uncertainty and project size are negatively associated with vendor profitability. From a knowledge-based view of the firm perspective, we hypothesize that industry knowledge and client knowledge are positively associated with vendor profitability. We tested these hypotheses on a comprehensive archival data set comprising 33,908 projects from a major vendor in the ERP software market. Our results confirm and extend previous research. Our results support the existence of two contractual regimes: effect sizes on vendor profitability are indeed much larger in FP contracts than in TM contracts. Also in line with prior research, our results suggest negative effects of project uncertainty and project size in terms of project budget on vendor profitability and positive effects of industry knowledge on vendor profitability. Contrary to prior knowledge, we find that project size in terms of project duration is significantly positively associated with vendor profitability in FP contracts. Also contrary to what is known, we find a significant negative effect of client knowledge on vendor profitabiliy in both contractual regimes.
\end{abstract}


Keywords: Outsourcing, transaction cost economics, knowledge-based view, vendor profitability, enterprise resource planning 


\section{INTRODUCTION}

Worldwide spending on enterprise resource planning (ERP) software reached 24.9 billion USD in 2012 making ERP software the largest segment of the enterprise application software market (Gartner Research, 2012). In contrast to stand-alone applications, ERP software features an enterprise-wide integrated database and various integrated applications that enable entering, recording, processing, monitoring, and reporting of all business transactions (Ragowsky, Somers, \& Adams, 2005). Organizations implement ERP software for a variety of reasons which range from technical, such as reducing maintenance costs, to business reasons, such as improving business processes (Markus \& Tanis, 2000). When conducting ERP projects, organizations typically outsource the project or parts of it to specialized vendors (Sarker, Sarker, Sahaym, \& Bjorn-Andersen, 2012). Although ERP outsourcing projects have considerable potential to create business value (Ragowsky, et al., 2005), they often fail whereby they consume substantial organizational resources and may even result in bankruptcy (Seddon, Calvert, \& Yang, 2010; Staehr, Shanks, \& Seddon, 2012; Sumner, 2000). The recent case of Avantor, in which Avantor sued its ERP vendor IBM for several million dollars in damages, highlights the risk that is inherent in these projects for both clients and vendors (Frost, 2012).

Given the high risk of failure in information systems (IS) outsourcing projects, it is not surprising that much of the literature on IS outsourcing has examined determinants of project success using a wide array of dependent and independent variables and various levels of analysis (Lacity, Khan, Yan, \& Willcocks, 2010). A frequently raised concern in the IS outsourcing discipline is that much of the literature exclusively examines the client's perspective on project success. The determinants of project success from a vendor's perspective have hardly been explored (Dibbern, Goles, Hirschheim, \& Jayatilaka, 2004; Lacity, et al., 2010; Levina \& Ross, 2003) resulting in a single-sided view on the success of outsourcing projects. Notable exceptions to this single sided-view include the studies by Gopal, Sivaramakrishnan, Krishnan, and Mukhopadhyay (2003), Ethiraj, Kale, Krishnan, and Singh (2005), Gopal and Sivaramakrishnan (2008) and Gopal and Koka (2012), who analyse vendor profitability - arguably one of the most important criteria of success from a vendor's perspective - in offshore software development outsourcing projects.

Building on this small body of research on offshore software development outsourcing projects, we investigate determinants of vendor profitability in domestic packaged software implementation outsourcing projects using the example of ERP projects under different contractual regimes. Following the rationale outlined in Gopal and Sivaramakrishnan (2008), we assume there are two different contractual regimes, i.e., fixed price (FP) contracts and time and material (TM) contracts, that govern the effect of these determinants. The effects on vendor profitability should be stronger in FP contracts as the vendor bears the major part of the risk in these contracts. Based on the logic of transaction cost economics (TCE) and knowledge-based view (KBV), we hypothesize that vendor profitability is negatively affected by project uncertainty and project size while vendor profitability is positively affected by client knowledge and industry knowledge (Sarker, et al., 2012). In contrast to software development projects, ERP vendors implement industry-specific software packages that enable them to capitalize on prior experiences within a given industry (Markus \& Tanis, 2000). We tested our hypotheses on a comprehensive data set from a major vendor in the ERP software market. Our data set comprises 33,908 ERP projects from 2,226 clients.

Our paper contributes in two ways to what is already known on the subject. First, we confirm some of the existing findings on the determinants of vendor profitability presented in the literature on offshore software development outsourcing projects. By doing so, we strengthen the confidence in these findings as applied across different forms of outsourcing. Second, we extend previous research in several ways. To the best of our knowledge, our study is the first to analyse determinants of vendor profitability in domestic packaged software implementation outsourcing projects using the example of ERP projects. In contrast to previous studies, our data set also provided us with the unique opportunity to analyse the vendor's profit margin thereby offering a more nuanced perspective on vendor 
profitability. Based on the KBV, we also add industry knowledge as an important determinant of vendor profitability in ERP projects.

The remainder of this paper is organized as follows: Section two describes the paper's conceptual background on contractual regimes in IS outsourcing projects and determinants of vendor profitability. Section three defines the research hypotheses on vendor profitability. In section four, we describe the research site and illustrate our approach to data collection and data analysis. In section five we present the results of our analysis. The paper concludes with a discussion of the study limitations, the contributions to existing research, and the implications of our study for practice.

\section{THERETICAL BACKGROUND}

\subsection{Contractual Regimes in IS outsourcing projects}

Formal contracts play an important role in determining the distribution of risk in a project (Lacity \& Hirschheim, 1993). There are two major types of contracts in IS outsourcing projects: FP contracts and TM contracts. While hybrid forms such as capped price contracts exist, pure FP and TM contracts seem to prevail in practice (Banerjee \& Duflo, 2000). In FP contracts, the vendor is responsible for delivering the project as specified by the client and is paid a fixed fee. Consequently, the major risk in FP contracts is borne by the vendor (Gopal, et al., 2003). In TM contracts, the client maintains responsibility for the project and pays the vendor an agreed fee per unit of effort the vendor delivers. The vendor's revenue for the project is not predetermined in this case. As a result, the client bears the risk of budget and schedule overruns in TM projects (Gopal, et al., 2003). From a vendor's perspective, the type of contract used for the project embodies a trade-off between risk protection (in TM contracts) and profitability potential (in FP contracts) (Gopal \& Sivaramakrishnan, 2008).

Based on variations in risk distribution (and given the primacy of profit maximization), each contract type presents different incentives for the vendor: FP contracts, which limit the vendor's revenues from a project, incentivize the vendor to minimize project costs. TM contracts, which limit the vendor's profit margin, incentivize the vendor to maximize effort and, thus, project revenues. Recent research has shown that vendors indeed manage FP contracts differently than TM contracts (Gopal \& Sivaramakrishnan, 2008). For instance, vendors assign more highly-trained staff to FP-based projects and monitor and control the project more rigorously (Kalnins \& Mayer, 2004). Conversely, vendors tend to over-deliver in TM contracts and accept change requests by the client more readily (Bajari \& Tadelis, 2001). The distinct risk distributions, incentive structures, and management mechanisms across the two contract types, make it reasonable to assume two contractual regimes with distinct profitability equations. We adopt the proposition by Gopal and Sivaramakrishnan (2008) that the effect sizes of the determinants of vendor profitability will differ depending on the contract type. Accordingly, instead of integrating the contract type as a binary variable in an overall profitability equation (Ethiraj, et al., 2005; Gopal, et al., 2003; Kalnins \& Mayer, 2004), we estimate two distinct profitability equations, one for FP contracts, and one for TM contracts (Gopal \& Sivaramakrishnan, 2008).

\subsection{Empirical Research on the Determinants of Vendor Profitability}

Empirical research on the determinants of vendor profitability in IS outsourcing projects is rare. Notable exceptions include the studies by Gopal, et al. (2003), Gopal and Sivaramakrishnan (2008), Gopal and Koka (2012), and Ethiraj, et al. (2005). Based on data collected on 93 offshore projects from an Indian software developer, Gopal, et al. (2003) investigate vendor contract preference and its effect on vendor profits. The authors provide empirical evidence that vendors purposefully chose between FP and TM contracts and that the chosen contract type and other project characteristics significantly affect project profits: All else being equal, TM contracts seem to be associated with higher profits. Additional project characteristics that were found to affect vendor profits include duration, team size, effort, client MIS experience, prior experience with the same client, requirements 
uncertainty, and the importance of the project to the client. Using the same data set, additional research by Gopal and Sivaramakrishnan (2008) and Gopal and Koka (2012) further highlights the role of contract type in determining vendor profits. Gopal and Sivaramakrishnan (2008) provide empirical evidence that FP and TM contracts feature distinctly different profit equations. Gopal and Koka (2012) illustrate that contract type moderates the effect of relational governance on vendor profits: given the vendor's higher risk exposure in FP contracts, relational governance seems to positively affect vendor profits in FP contracts only. Also studying project-level data from an Indiabased software development company, Ethiraj, et al. (2005) investigate the importance of capabilities in determining vendor project profits. Their results suggest that two classes of capabilities, clientspecific capabilities and project management capabilities, are positively associated with higher vendor profits.

\section{RESEARCH HYPOTHESES}

Our research model builds on TCE and KBV which are two commonly used theories in IS outsourcing (Dibbern, Winkler, \& Heinzl, 2008). Based on the assumptions of bounded rationality and opportunism, TCE suggests that the most efficient structure for governing a transaction depends on the costs that arise for "planning, adapting, and monitoring task completion" (Williamson, 1981, p. p. 552). These transaction costs derive from characteristics of the transaction itself, such as the frequency, the specificity, or the uncertainty of the transaction (Williamson, 1979). Our data set allows us to relate two key transaction characteristics, i.e., project uncertainty and project size, to vendor profitability. As described below in more detail, we argue that these characteristics result in additional transaction costs and thus negatively affect vendor profitability.

KBV derives from the resource-based view (RBV) of the firm (Barney, 1991; Penrose, 1959) and regards knowledge as "the most strategically important of a firm's resources" (Grant, 1996, p. p. 110). A firm's knowledge evolves over time through individual learning (Grant, 1996). Knowledge forms the basis for a firm's unique organizational capabilities that are, in turn, the source of its competitive advantage and its ability to generate rents (Ethiraj, et al., 2005; Grant, 1996). In this paper, we distinguish between industry knowledge and client knowledge, both of which are suggested to be a function of repeated transactions in the same industry and with the same client, respectively (Ethiraj, et al., 2005). We argue that both forms of knowledge allow vendors to operate more efficiently and thus positively affect vendor profitability.

The effect of these determinants on vendor profitability depends on the contract type. As stated above, the risk in FP contracts is borne by the vendor. The effect of the determinants on vendor profitability should, consequently, be greater in FP contracts than in TM contracts. While the contract allocates the major risks to either vendor (in FP contracts) or client (in TM contracts), it does not allocate all the risk to one of the contracting parties exclusively. As contracts are necessarily incomplete (Hart \& Moore, 1988), contingencies that arise during the project are frequently resolved in settlements with both parties bearing some of the additional costs. Thus, even in TM contracts, the vendor may incur additional costs.

We control for several variables that are known to have an effect on vendor profitability: the size of the client, the vendor's relative market share at the time of the project, the client's area of business, and the year in which the project takes place. The size of the client has been found to be negatively associated with the vendor's bargaining power (Mjoen \& Tallman, 1997). In a similar vein, the vendor's relative market share at the time of the transaction indicates the vendor's market position, which may affect the vendor's bargaining power and thus vendor profitability (Gopal, et al., 2003). Finally, we control for variations in vendor profitability across industries and over time (Ethiraj, et al., 2005). Figure 1 depicts our research model.

[INSERT FIGURE 1 HERE] 
Uncertainty is one of the critical dimensions for describing transactions in transaction cost economics (Williamson, 1979) and is a well-known risk factor in the IS project management literature (McFarlan, 1981; Nidumolu, 1995; Zmud, 1980). According to Zmud (1980, p. p. 46), "most difficulties can be traced to the uncertainty that pervades software development. Software development is an information-intensive activity, and decision points are continually reached where the decision maker possesses inadequate information". Similar to software development projects, packaged software implementation projects, and particularly ERP projects, comprise many information-intensive activities, such as creating process models or organizational models (Scheer \& Habermann, 2000). High degrees of uncertainty relating to the requirements and the technology used in the project have been shown to negatively affect project performance (Nidumolu, 1995). In the case of uncertain transactions, contractual gaps will be larger, increasing the number of adaptations, and making it necessary for the contracting parties to devise more sophisticated coordination mechanisms to "work things out" (Williamson, 1979, p. p. 254). This need for additional coordination mechanisms will increase transaction costs and thus negatively affect vendor profitability. As the vendor bears the major part of the risk in FP contracts, we hypothesize:

Hypothesis 1 (H1): There will be a greater negative association between project uncertainty and vendor profitability in FP contracts than in TM contracts.

In addition to uncertainty, project size is an important and well-researched characteristic of IS projects. Although not a core variable of TCE, literature on IS project management frequently mentions the size of a project, often characterized through proxies such as the budget or duration of a project, as one of the major risk factors in IS projects that can cause higher transaction costs (McFarlan, 1981; Ropponen \& Lyytinen, 2000). Costs for planning, adapting, and monitoring a project are increased in larger projects as rising complexity and task interdependence typically lead to greater volatility and a higher risk of underperforming (Gemino, Reich, \& Sauer, 2008; Sauer, Gemino, \& Reich, 2007; Yetton, Martin, Sharma, \& Johnston, 2000). The additional transaction costs for planning, adapting, and monitoring larger projects will be shared in some form between the client and the vendor and negatively affect the vendor's profitability (Williamson, 1979). Again, as the vendor bears the major part of the risk in FP projects, we hypothesize:

Hypothesis 2 (H2): There will be a greater negative association between project size and vendor profitability in FP contracts than in TM contracts.

Knowledge is widely regarded as a valuable resource for a firm that is hard to imitate and leads to competitive advantages (Prahalad \& Hamel, 1990). In particular, KBV regards knowledge as "the most strategically important of the firm's resources" (Grant, 1996, p. p. 110). Knowledge accumulates over time through learning by doing and is embedded in the firm's organizational capabilities (Ethiraj, et al., 2005). With increasing knowledge, firms tend to become more effective and efficient in the activities they engage in. Conversely, a lack of knowledge has been frequently found to negatively affect project performance (Gemino, et al., 2008; Jiang \& Klein, 2000; Jun, Qiuzhen, \& Qingguo, 2011). In the case of IS outsourcing projects, vendors accumulate technical knowledge (Bharadwaj, 2000) in the design and implementation of their solutions. As ERP software, e.g., core banking software, is highly industry-specific (Davenport, 1998; Markus \& Tanis, 2000), we argue that learning will occur with repeated interactions within the same industry, increasing an ERP vendor's technical knowledge. Knowledge-enabled efficiency gains and price premiums should positively affect vendor profitability. Given the two different contractual regimes, this association should be stronger in FP contracts. Thus, we hypothesize:

Hypothesis 3 (H3): There will be a greater positive association between industry knowledge and vendor profitability in FP contracts than in TM contracts.

In addition to industry knowledge, vendors will also accumulate client knowledge through repeated interactions with the same client (Ethiraj, et al., 2005; Gefen, Wyss, \& Lichtenstein, 2008). Client knowledge relates to the cumulated knowledge of the client's business environment and its operating routines (Ethiraj, et al., 2005). Literature sources argue that client knowledge enables vendors to 
reduce risk in IS outsourcing projects by allocating the right resources to the client (Gefen, et al., 2008). Client knowledge forms unique capabilities that establish, in turn, competitive advantages and allow the vendor to generate higher rents (Ethiraj, et al., 2005; Grant, 1996). For instance, in the case of ERP projects, knowledge about the client's legacy systems might prove particularly valuable for the vendor. As the design of interfaces to legacy systems is often considered a major risk factor in ERP projects (Markus \& Tanis, 2000; Sumner, 2000), knowing the characteristics of the client's legacy systems will help the vendor to avoid completion delays and the associated higher costs. This understanding of the client's infrastructure and business processes serves as a competitive advantage. Closely linked to the concept of client knowledge is the concept of trust that develops through repeated interactions with the same client (Gefen, et al., 2008). Trust simplifies communication between the client and the vendor and reduces the necessity of specifying costly governance mechanisms such as monitoring controls and extensively detailed contracts (Gefen, et al., 2008; Williamson, 1979). Both client knowledge and trust increase with the number of projects with the same client. These outcomes of the client-vendor relationship allow the vendor to operate more efficiently and demand higher prices (Ethiraj, et al., 2005). Again, given two contractual regimes, the effects of client knowledge should be greater in FP contracts. We hypothesize:

Hypothesis 4 (H4): There will be a greater positive association between client knowledge and vendor profitability in FP contracts than in TM contracts.

\section{METHODOLOGICAL APPROACH}

\section{1 $\quad$ Research Site and Data Collection}

Our industry partner ALPHA is a major vendor in the ERP services market. ALPHA offers implementation as well as post-implementation services to clients from a vast range of industries. These services are conducted as projects. We follow the definition of Pressman (2005) in defining an IS project as a separate and identifiable series of tasks or activities undertaken to achieve a specific IS objective within certain technical specifications with relatively well-defined start and end dates.

We tested our hypotheses on an archival dataset of ALPHA containing all projects of ALPHA's German consulting unit that were conducted between 2004 and 2011. The raw data comprised 40,271 records. Because of our focus on domestic outsourcing, we excluded projects with clients from Austria and Switzerland and ALPHA internal projects ( $\mathrm{n}=505$ records). We also excluded records that did not match our definition of a project, e.g., workshops without any technical specifications and projects conducted with hybrid contract type $(n=2,375)$. We excluded projects for which we could not identify the client and, consequently, could not determine employee or industry values $(n=2,793)$. Following the recommendations by Eriksson, et al. (2006), we corrected for outliers by discarding one per cent $(1 \%)$ of the highest and the lowest profitability values $(n=690)$. The remaining dataset comprises 33,908 projects from 2,227 different clients. A TM contract was used for 30,508 projects and 3,400 projects were conducted using a FP contract. The projects cover a broad range of industries with a focus on manufacturing (45\%), services (17\%), and finance, insurance and real estate (17\%).

The variable descriptions are shown in Error! Reference source not found..

[INSERT TABLE 1 HERE]

ALPHA monitors their projects very closely. Most of our data are project-level data from one of ALPHA's controlling systems, which is used to track revenue and costs of consulting projects. The revenue figures refer to consulting services only, that is, they do not include revenue from software sales. We extracted the profit margin, the project budget, the actual project revenue, the project duration, the client's name and the year of project begin directly from the system. The client's industry, the client's size and ALPHA's relative market share at the time of each project were obtained using external company databases. We calculated proxies for industry knowledge, client knowledge 
and project uncertainty. The descriptive statistics of the metric variables are presented in Error! Reference source not found.

\section{[INSERT TABLE 2 HERE]}

In contrast to previous studies (Ethiraj, et al., 2005; Gopal \& Sivaramakrishnan, 2008; Gopal, et al., 2003), our data set allows us to measure vendor profitability with the vendor's profit margin instead of the vendor's absolute profits. The profit margin was extracted directly from the system. It is calculated by multiplying the share of project profit on project revenue by 100 . Project uncertainty was approximated by multiplying the absolute value of the share of actual project revenue on project budget by 100 (Ethiraj, et al., 2005; Sauer, et al., 2007). Deviations of actual project revenue from project budget are frequently the result of scope changes and thus a good proxy for project uncertainty (Sauer, et al., 2007). Project size was approximated using two proxies: project budget and project duration. To make project budgets from different years comparable, the data must be adjusted for inflation. Adjusting for inflation is far from trivial since identifying an appropriate price index specific to an ERP vendor is quite difficult (Ethiraj, et al., 2005). However, we discovered that we could implicitly adjust for inflation by taking the log of project budget and including year dummies in the regression estimation. In doing so, the year dummies absorb the inflation effect and the estimation results for project budget remain unaffected. A detailed explanation of this calculation is provided in Ethiraj, et al. (2005). Industry knowledge was calculated as the number of previous projects conducted by ALPHA within the same industry according to the major group level of the Standard Industry Classification (SIC). In a similar way, we approximated client knowledge by calculating the number of previous projects conducted by ALPHA with the same client (Ethiraj, et al., 2005; Gopal \& Sivaramakrishnan, 2008; Gopal, et al., 2003). As we did not have access to projects conducted prior to 2004 , it should be noted that we use conservative approximations of vendor's industry and client knowledge. Client size was measured using the client's number of employees at the beginning of the project (Gopal \& Sivaramakrishnan, 2008; Gopal, et al., 2003). The number of client employees was obtained using external company databases. We calculated ALPHA's relative market share in a given year by dividing ALPHA's revenues by the revenues of ALPHA's biggest competitor. The revenues of ALPHA's competitors were obtained using yearly rankings of the Top-25 ERP vendors in Germany (Luenendonk, 2012).

\subsection{Data Analysis}

We tested our hypotheses using the following ordinary least squares specification:
Vendor profitability ${ }_{i}=\alpha_{i}+\beta_{1} \ln \left(\right.$ project $\left._{\text {uncertainty }}+1\right)+\beta_{2} \ln \left(\right.$ project $\left._{\text {budget }}\right)+\beta_{3} \ln ($ project duration $\left._{i}\right)+\beta_{4} \ln \left(\right.$ industry knowledge $\left._{i}+1\right)+\beta_{5} \ln \left(\right.$ client knowledge $\left._{i}+1\right)+\beta_{6} \ln \left(\right.$ client size $\left._{i}\right)+\beta_{7}$ relative market share ${ }_{i}+\beta_{8}$ year $_{i}+\beta_{9}$ industry $_{i}+\beta_{10} \lambda_{i}+\varepsilon_{i}$

where $\mathrm{i}$ indexes the individual projects and $\varepsilon_{\mathrm{i}}$ is an error term. To reduce skewness, the variables project uncertainty, project budget, project duration, industry knowledge, client knowledge and client size were log-transformed (Hair, Black, Babin, Anderson, \& Tatham, 2006).

It is important to note that contract type is potentially endogenous. The concept of endogeneity implies that the contract type itself is a function of ex ante expectations of profitability, i.e., organizations choose contract types that result in the greatest expected profitability under the given conditions (Banerjee \& Duflo, 2000; Gopal \& Sivaramakrishnan, 2008; Kalnins \& Mayer, 2004). When organizations purposefully choose contract types, regressing profitability on a set of independent variables will not accurately capture how these variables affect profitability unless one of two conditions holds: (i) organizations regularly make errors so that contract type can be assumed to be random, or, (ii) all factors that affect profitability can be incorporated in the empirical model that 
estimates profitability (Shaver, 1998). As neither condition holds in our setting, correcting for endogeneity is necessary to obtain unbiased and consistent estimates from ordinary least squares (Maddala, 1983).

We corrected for endogeneity using the two stage procedure proposed by Heckman (1979) and outlined in Hamilton and Nickerson (2003). In the first stage, a probit specification was used to capture the effects of variables available to the vendor prior to project start on contract type (see Error! Reference source not found. in the Appendix). Using these results, we then calculated the inverse Mill's ratio. In the second stage, the inverse Mill's ratio was included in the profitability equation as an additional variable $\left(\lambda_{i}\right)$.

Estimation results are shown in Error! Reference source not found.. As proposed by Shaver (1998), we contrasted the endogeneity-corrected results with the uncorrected results as an additional check for robustness. We used clustered standard errors in cases where clients engaged in multiple projects. No assumptions underlying ordinary least squares were rejected: there was no sign of heteroscedasticity. The highest variance inflation factor (VIF) was 5.12, which is below the commonly used thresholds (Hair, et al., 2006), suggesting no multicollinearity (Belsey, Kuh, \& Welsch, 1980). The residuals were normally distributed in the FP-model. In the TM-model, there was a slight deviation of the residuals from normality. Because the detrimental effects of non-normality are reduced in large samples, we had no reason to be concerned about the slight deviation from normality in the TM-model (Hair, et al., 2006).

\section{[INSERT TABLE 3 HERE]}

The adjusted $\mathrm{R}^{2}$ for the FP-model is 0.11 . Project uncertainty is not significantly associated with vendor profitability. Project budget is significantly negatively associated with vendor profitability. Project duration and industry knowledge are significantly positively associated with vendor profitability. There seems to be no systematic effect of client knowledge on vendor profitability. The inverse Mill's Ratio is significant indicating significant endogeneity (Shaver, 1998).

The adjusted $\mathrm{R}^{2}$ for the TM-model is 0.06 . Project uncertainty, project budget, project duration and client knowledge are significantly negatively associated with vendor profitability. Industry knowledge is significantly positively associated with vendor profitability. The inverse Mill's Ratio is not significant indicating no significant endogeneity (Shaver, 1998).

Both models are highly significant at the $0.1 \%$ level. Neither the signs nor the significance of the main coefficients change in the endogeneity-corrected models, which suggests robust results.

\section{DISCUSSION}

\section{$5.1 \quad$ Summary of Results}

The rationale of our analysis was to investigate the effect of theoretically grounded determinants of vendor profitability in ERP projects under two different contractual regimes. We tested our hypotheses on a unique archival dataset of 33,908 projects from a major ERP vendor. Our results suggest that indeed two different contractual regimes exist with greater effect sizes in FP contracts than in TM contracts.

We found tentative support for our hypothesis H1 (There will be a greater negative association between project uncertainty and vendor profitability in FP contracts than in TM contracts). While FP contracts are more negatively affected by project uncertainty than TM contracts, the association is only significant in the TM sample. We argue that ALPHA is able to manage uncertainty particularly well in FP projects, probably because ALPHA assigns more experienced project managers to these projects. This is in line with the rationale provided by Kalnins and Mayer (2004).

We found mixed support for our hypothesis $\mathrm{H} 2$ (There will be a greater negative association between project size and vendor profitability in FP contracts than in TM contracts). Our findings show a 
significant negative effect of project budget on vendor profitability, which is greater in FP contracts, thus fully supporting $\mathrm{H} 2$. However, while project duration significantly negatively affects vendor profitability in TM-based projects, we found a highly significant positive effect of project duration on vendor profitability in FP contracts, which does not support H2. A possible explanation for this surprising result is that project budget and project duration are indeed two different dimensions of project size (Sauer, et al., 2007). While project budget seems to increase complexity and task interdependence (Gemino, et al., 2008; Yetton, et al., 2000), project duration might actually provide additional flexibility in that vendors have time to react to unforeseen contingencies and fully leverage their pools of resources. Vendors might be able to effectively convince the client to pay higher prices in FP contracts because external influences become more apparent as project duration is prolonged. This line of reasoning may not be put forward by the vendor in TM contracts where the client bears the major risks associated with the project.

In strong support of hypothesis H3 (There will be a greater positive association between industry knowledge and vendor profitability in FP contracts than in TM contracts) we found a significant positive effect of industry knowledge on vendor profitability in both types of contract. The effect size is around five times larger in FP-based projects than in TM-based projects. Our results suggest that with repeated interactions within one industry, ALPHA accumulates technical knowledge that allows for more efficient project operations. Industry knowledge is likely to be particularly valuable for the vendor in the case of ERP software, which is specifically designed to fit the needs of a given industry (Markus \& Tanis, 2000).

Our results do not support $\mathrm{H} 4$ (There will be a greater positive association between client knowledge and vendor profitability in FP contracts than in TM contracts). While the effect size of client knowledge is greater in the FP sample, we found significant negative effects of client knowledge on vendor profitability in both contractual regimes. Given the strong theoretical underpinning that repeated interactions with the same client should lead to knowledge and trust-related benefits for the vendor (Gefen, et al., 2008), this result is surprising. Our findings are, however, consistent with the empirical evidence presented in Gopal, et al. (2003). Post-hoc interviews with ALPHA's risk managers suggested a plausible explanation for this: in repeated interactions with the same client, the rising technical complexity of more specialized ERP modules outweighs the knowledge and trustrelated benefits. Apart from that, it seems likely that as the client becomes more familiar with the vendor's capabilities and cost structures, the vendor's potential to seek rents from private information decreases (Gefen, et al., 2008).

\subsection{Study Limitations}

We acknowledge two study limitations. Firstly, because our data stem from one ERP vendor only, issues concerning the generalizability of our results have to be taken into account. Although ALPHA's considerable market share makes our sample reasonably representative of German ERP outsourcing projects, our findings might not be transferable to other ERP vendors. For instance, ALPHA's distinct set of resources might enable it to better handle contingencies related to project uncertainty or project size or to better leverage industry knowledge and client knowledge. This might result in idiosyncratic effects for the analyzed determinants of vendor profitability.

Secondly, while our data archive is unique in terms of its size, breadth, and up-to-datedness, it restricts us to a limited selection of independent variables. As indicated by the low adjusted $\mathrm{R}^{2}$ values of both our models, this selection of independent variables is theoretically incomplete. For instance, another important variable from a TCE perspective is asset specificity (Williamson, 1981). Asset specificity denotes the extent to which investments by the vendor are specialized to a particular transaction. Specialized investments, in the form of specifically trained personnel, in turn expose the vendor to client opportunistic behaviour and potentially lower project profitability. However, theoretically incomplete models and low values of adjusted $\mathrm{R}^{2}$ are not uncommon when investigating complex social phenomena (Wooldridge, 2002). Since the objective of this paper is not to predict vendor 
profitability but rather to test theoretically grounded relationships, we are more interested in reliable estimates of the ceteris paribus effects of our independent variables than in high values of adjusted $\mathrm{R}^{2}$ (Wooldridge, 2002).

\subsection{Contributions to Research}

This paper advances the understanding of vendor profitability in IS outsourcing projects by confirming and extending previous research. Our research confirms the existence of two distinct contractual regimes as proposed by Gopal and Sivaramakrishnan (2008). The effect of our independent variables on vendor profitability differs considerably depending on whether the contract is of the FP or TM type.

In particular, our results confirm the finding by Ethiraj, et al. (2005) that uncertainty in projects, as indicated by the difference between actual project revenues and project budget, negatively affects vendor profitability. Ethiraj, et al. (2005) interpret differences between actual project revenues and project budget as a consequence of missing project management capabilities on the vendor's side. Given ALPHA's distinct project management capabilities, it is not surprising that the effect of uncertainty on vendor profitability is quite small in our sample.

Our findings are consistent with previous research (Gopal, et al., 2003) in showing that client knowledge tends to be negatively associated with vendor profitability. While at first glance this may be counter-intuitive, post-hoc interviews with risk managers at ALPHA offered a plausible explanation for this finding. In repeated interactions with the same client, projects tend to become more complex. The increased technical complexity in these projects seems to outweigh the benefits that occur through increased trust and knowledge obtained through repeated interactions. This explanation in particular holds true for ERP projects in which an initial implementation of an ERP platform is followed by more customized and more complex modules.

To the best of our knowledge, our study is the first to analyse determinants of vendor profitability in domestic packaged software implementation outsourcing as called for by Gopal, et al. (2003). Previous research exclusively focused on offshore software development outsourcing (Ethiraj, et al., 2005; Gopal \& Koka, 2012; Gopal \& Sivaramakrishnan, 2008; Gopal, et al., 2003).

Our results contribute to the existing literature by re-conceptualizing vendor profitability. In contrast to previous studies (Ethiraj, et al., 2005; Gopal \& Koka, 2012; Gopal \& Sivaramakrishnan, 2008; Gopal, et al., 2003), which use absolute profits as a proxy for vendor profitability, we employed the ratio of project profits to project revenues, i.e., the profit margin, as our dependent variable. The profit margin is in some respect a more precise indication of vendor profitability than absolute profits as it comprises the notion of efficient resource allocation. Given our re-conceptualization of vendor profitability, we arrived at different results concerning the association between project size and vendor profitability. It is not surprising that project size drives absolute vendor profits (Ethiraj, et al., 2005; Gopal \& Koka, 2012; Gopal \& Sivaramakrishnan, 2008; Gopal, et al., 2003): absolute vendor profits are naturally higher in larger projects with a prolonged duration. However, it is less intuitive that project size should drive vendor profitability in terms of the profit margin. Project size is known to increase organizational complexity and drive budget and schedule overruns (Sauer, et al., 2007) and therefore should reduce the vendor's profit margin. Furthermore, the benefits that the vendor gains from large projects, e.g., reputational gains or longer-term utilization of staff, should induce the vendor to offer price discounts which further decrease the vendor's profit margin. Our data strongly support this hypothesis. In contrast to previous studies (Ethiraj, et al., 2005; Gopal \& Koka, 2012; Gopal \& Sivaramakrishnan, 2008; Gopal, et al., 2003), we found a negative effect of project size (in terms of budget) on vendor profitability. Surprisingly, our results are mixed with regard to the association between project size in terms of project duration and vendor profitability. While in FPbased projects duration seems to have a positive effect on vendor profitability, we found a negative effect on vendor profitability in TM-based projects. We provide two plausible explanations for this. First, the vendor might be able to react more flexibly to unforeseen contingencies in longer-term FP 
contracts. Because the vendor bears the lion's share of the risk in FP contracts, the vendor benefits from the increased flexibility that comes with longer project duration in FP projects only. Second, longer FP contracts might allow the vendor to negotiate particularly large financial reserves to compensate for unforeseen contingencies. Again, this explanation applies to FP contracts only as the vendor's need for financial reserves is considerably lower in TM contracts.

Finally, following the rationale of KBV, our results introduce industry knowledge as an important determinant of vendor profitability in ERP projects. We argue that industry knowledge is particularly important for ERP vendors because ERP software tends to be standardized within one industry, which enables considerable learning effects across clients within the same industry. While there might be positive effects of industry knowledge in software development projects, these effects are likely to be weaker due to their more idiosyncratic nature (Markus \& Tanis, 2000).

Our contributions to existing knowledge are strengthened by the unique archival data set used in our analysis. In general, analyses based on archival data avoid common method bias (Podsakoff, MacKenzie, Lee, \& Podsakoff, 2003) and may thus provide better estimations of coefficients and explained variance (Gefen, et al., 2008). The value of archival data seems to be acknowledged when analysing vendor profitability in outsourced IS projects (Ethiraj, et al., 2005; Gopal \& Koka, 2012; Gopal \& Sivaramakrishnan, 2008; Gopal, et al., 2003). In comparison to previously used archival data sets, our current data set stands out in terms of its size, breadth, and up-to-datedness. With a sample size of 33,908 projects, we were able to find considerable variation in our independent variables allowing for more precise estimations of their coefficients (Wooldridge, 2002). The detailed financial data available on revenues and costs of the projects enabled us to investigate vendor profitability in terms of profit margin instead of absolute profits. As previously stated, the vendor's profit margin is likely to be a more precise indication of vendor profitability than absolute profit. Finally, because the data set used in this study came from projects conducted between 2004 and 2011, our insights on the determinants of vendor profitability were gained from fairly current business practices.

\subsection{Implications for practice}

By analysing the effect of project uncertainty, project size, industry knowledge and client knowledge on vendor profitability for two different types of contracts, the results of our study provide several managerial implications for vendors.

Irrespective of the type of contract, TM-based or FP-based, we found that reducing project uncertainty tends to result in higher profit margins for the vendor. Even in TM-based projects where the financial risk is transferred to the client, reducing uncertainty by ensuring clear requirements and project objectives should benefit vendor profitability. Given the negative effect of project size (in terms of effort) on vendor profitability seen in both types of contracts, vendors should try to split larger projects into several smaller ones in order to decrease organizational complexity. Though the association between size and profitability might also stem from discounts on the bid price that the vendor offers to the client in the case of larger projects, the complexity effect seems plausible given the frequent budget and schedule overruns in large IS projects (Sauer, et al., 2007; Yetton, et al., 2000). Because of the positive relationship between duration and vendor profitability in FP-based projects, vendors should negotiate sufficiently ample time for project completion in order to maintain valuable flexibility in these projects. Alternatively, projects of shorter duration should include higher risk premiums. In TM-based projects, where the client tends to be responsible for the project management, vendors might try to push for more stringent project control in order to avoid costly schedule overruns.

We found modest evidence that vendor profitability decreases in repeat projects with the same client. As increases in complexity might be one reason for this finding, raising risk premiums or establishing a more effective project governance could be options to sustain the profit margin. Finally, our analysis suggests considerable learning effects in repeat projects within the same industry, illustrating the high value of industry knowledge in ERP outsourcing projects for vendors. 


\section{CONCLUSION}

This paper answers the call for more studies on the vendor's perspective in the domain of IS outsourcing (Dibbern, et al., 2004; Levina \& Ross, 2003). We investigated the effect of project uncertainty, project size, industry knowledge and client knowledge on the vendor's profit margin in FP and TM contractual arrangements. We found that the effect sizes of the determinants of vendor profitability vary considerably between the two types of contracts. Furthermore, while project uncertainty, project budget and client knowledge seem to negatively affect vendor profitability, we found that industry knowledge positively effects vendor profitability. The effect of project duration on profitability is positive in FP contracts and negative in TM contracts. Our findings contribute to the IS outsourcing literature by confirming the existence of two contractual regimes (Gopal \& Sivaramakrishnan, 2008) and by providing a more nuanced view on the determinants of vendor profitability in domestic packaged software implementation projects (Gopal, et al., 2003). Future research should look into further determinants of vendor profitability. In particular, investigating the relationship between repeated interactions with the same client, client knowledge and technical complexity would build on the knowledge foundation we have created. Given the considerable importance of the contractual regime in determining vendor profitability, analysing the effects of other types of contractual provisions, such as dispute resolutions or rewards and sanctions, on vendor profitability would be of benefit for clients and vendors. 


\section{REFERENCES}

Bajari, P. and Tadelis, S. (2001) Incentives versus transaction costs: A theory of procurement contracts. The RAND Journal of Economics, 32(3): 387-387.

Banerjee, A. and Duflo, E. (2000) Reputation effects and the limits of contracting: A study of the Indian software industry. Quarterly Journal of Economics, 115(3): 989-1017.

Barney, J. (1991) Firm resources and sustained competitive advantage. Journal of Management, 17(1): 99-120.

Belsey, D., Kuh, E., and Welsch, R. (1980) Regression diagnostics: Identifying influential data and sources of collinearity. New York: John Wiley \& Sons.

Bharadwaj, A. (2000) A resource-based perspective on information technology capability and firm performance: An empirical investigation. MIS Quarterly, 24(1): 169-196.

Davenport, T. (1998) Putting the enterprise into the enterprise system. Harvard Business Review, 76(4): 121-131.

Dibbern, J., Goles, T., Hirschheim, R., and Jayatilaka, B. (2004) Information systems outsourcing: a survey and analysis of the literature. SIGMIS Database, 35(4): 6-102.

Dibbern, J., Winkler, J., and Heinzl, A. (2008) Explaining variations in client extra costs between software projects offshored to India. MIS Quarterly, 32(2): 333-366.

Eriksson, L., Johansson, E., Kettaneh-Wold, N., Trygg, J., Wikstroem, C., and Wold, S. (2006) Multiand megavariate data analysis: Advanced applications and method extensions. Umea: Umetrics.

Ethiraj, S., Kale, P., Krishnan, M., and Singh, J. (2005) Where do capabilities come from and how do they matter: A study in the software services industry. Strategic Management Journal, 26(1): 25-45.

Frost, L. (2012) Avantor files suit against IBM over failed SAP implementation. Chemical Week, 174(29): 12-12.

Gartner Research. (2012). Global IT spending forecast. Stamford: Gartner Research.

Gefen, D., Wyss, S., and Lichtenstein, Y. (2008) Business Familiarity as Risk Mitigation in Software Development Outsourcing Contracts. MIS Quarterly, 32(3): 531-542.

Gemino, A., Reich, B., and Sauer, C. (2008) A temporal model of information technology project performance. Journal of Management Information Systems, 24(3): 9-44.

Gopal, A. and Koka, B. (2012) The asymmetric benefits of relational flexibility: Evidence from software development outsourcing. MIS Quarterly, 36(2): 553-576.

Gopal, A. and Sivaramakrishnan, K. (2008) On vendor preferences for contract types in offshore software projects: The case of fixed price vs. time and materials contracts. Information Systems Research, 19(2): 202-220.

Gopal, A., Sivaramakrishnan, K., Krishnan, M., and Mukhopadhyay, T. (2003) Contracts in offshore software development: An empirical analysis. Management Science, 49(12): 1671-1683.

Grant, R. (1996) Toward a knowledge-based theory of the firm. Strategic Management Journal, 17(Special Issue): 109-122.

Hair, J., Black, W., Babin, B., Anderson, R., and Tatham, R. (2006) Multivariate data analysis. New Jersey: Pearson Education.

Hamilton, B. and Nickerson, J. (2003) Correcting for endogeneity in strategic management research. Strategic Organization, 1(1): 51-78.

Hart, O. and Moore, J. (1988) Incomplete contracts and renegotiation. Econometrica, 56(4): 755-785.

Heckman, J. (1979) Sample selection bias as a specification error. Econometrica, 47(1): 153-161.

Jiang, J. and Klein, G. (2000) Software development risks to project effectiveness. Journal of Systems \& Software, 52(1): 3-10.

Jun, L., Qiuzhen, W., and Qingguo, M. (2011) The effects of project uncertainty and risk management on IS development project performance: A vendor perspective. International Journal of Project Management, 29(7): 923-933. 
Kalnins, A. and Mayer, K. (2004) Relationships and hybrid contracts: An analysis of contract choice in information technology. Journal of Law, Economics, and Organization, 20(1): 207-229.

Lacity, M. and Hirschheim, R. (1993) Information systems outsourcing: Myths, metaphors and realities. New York: John Wiley \& Sons.

Lacity, M., Khan, S., Yan, A., and Willcocks, L. (2010) A review of the IT outsourcing empirical literature and future research directions. Journal of Information Technology, 25(4): 395-433.

Levina, N. and Ross, J. (2003) From the vendor's perspective: exploring the value proposition in information technology outsourcing. MIS Quarterly, 27(3): 331-364.

Luenendonk. (2012). TOP 25 IT-Beratungs- und Systemintegrations-Unternehmen in Deutschland 2012. Kaufbeuren: Luenendonk.

Maddala, G. (1983) Limited-dependent and qualitative variables in econometrics. Cambridge: Cambridge University Press.

Markus, L. and Tanis, C. (2000). The enterprise system experience: From adoption to success. In R. Zmud (Ed.), Framing the domains of IT management: Predicting the future through the past (Cincinatti: Pinnaflex Educational Resources, pp. 173-207.

McFarlan, W. (1981) Portfolio approach to information systems. Harvard Business Review, 59(5): 142-151.

Mjoen, H. and Tallman, S. (1997) Control and performance in international joint ventures. Organization Science, 8(3): 257-275.

Nidumolu, S. (1995) The effect of coordination and uncertainty on software project performance: residual performance risk as an intervening variable. Information Systems Research, 6(3): 191.

Penrose, E. (1959) The theory of the growth of the firm. New York: Blackwell.

Podsakoff, P., MacKenzie, S., Lee, J.-Y., and Podsakoff, N. (2003) Common method biases in behavioral research: A critical review of the literature and recommended remedies. The Journal of Applied psychology, 88(5): 879-903.

Prahalad, C. and Hamel, G. (1990) The core competence of the corporation. Harvard Business Review1, 68(3): 79-91.

Pressman, R. (2005) Software engineering: A practitioner's approach. New York: McGraw-Hill Higher Education.

Ragowsky, A., Somers, T., and Adams, D. (2005) Asessing the value provided by ERP applications through organizational activities. Communications of the AIS, 2005(16): 381-407.

Ropponen, J. and Lyytinen, K. (2000) Components of software development risk: How to address them: A project manager survey. IEEE Transactions on Software Engineering, 26(2): 98-112.

Sarker, S., Sarker, S., Sahaym, A., and Bjorn-Andersen, N. (2012) Exploring value cocreation in relationships between an ERP vendor and its partners: A revelatory case stury. MIS Quarterly, 36(1): 317-338.

Sauer, C., Gemino, A., and Reich, B. (2007) The impact of size and volatility on IT project performance. Communications of the ACM, 50(11): 79-84.

Scheer, A.-W. and Habermann, F. (2000) Making ERP a success. Communications of the ACM, 43(4): 57-61.

Seddon, P., Calvert, C., and Yang, S. (2010) A multi-project model of key factors affecting organizational benefits from enterprise systems. MIS Quarterly, 34(2): 305-328.

Shaver, M. (1998) Accounting for endogeneity when assessing stragegy performance: Does entry mode choice affect FDI survival. Management Science, 44(4): 571-585.

Staehr, L., Shanks, G., and Seddon, P. (2012) An explanatory framework for achieving business benefits from ERP systems. Journal of the Association for Information Systems, 13(6): 424465.

Sumner, M. (2000) Risk factors in enterprise-wide/ERP projects. Journal of Information Technology, 15(4): 317-327.

Williamson, O. (1979) Transaction-cost economics: The governance of contractual relations. Journal of Law and Economics, 22(2): 233-261.

Williamson, O. (1981) The economics of organization: The transaction cost approach. The American Journal of Sociology, 87(3): 548-577. 
Wooldridge, J. (2002) Econometric analysis of cross section and panel data. Cambridge: MIT Press.

Yetton, P., Martin, A., Sharma, R., and Johnston, K. (2000) A model of information systems development project performance. Information Systems Journal, 10(4): 263-289.

Zmud, R. (1980) Management of large software development efforts. MIS Quarterly, 4(2): 45-56. 


\section{FIGURES AND TABLES}

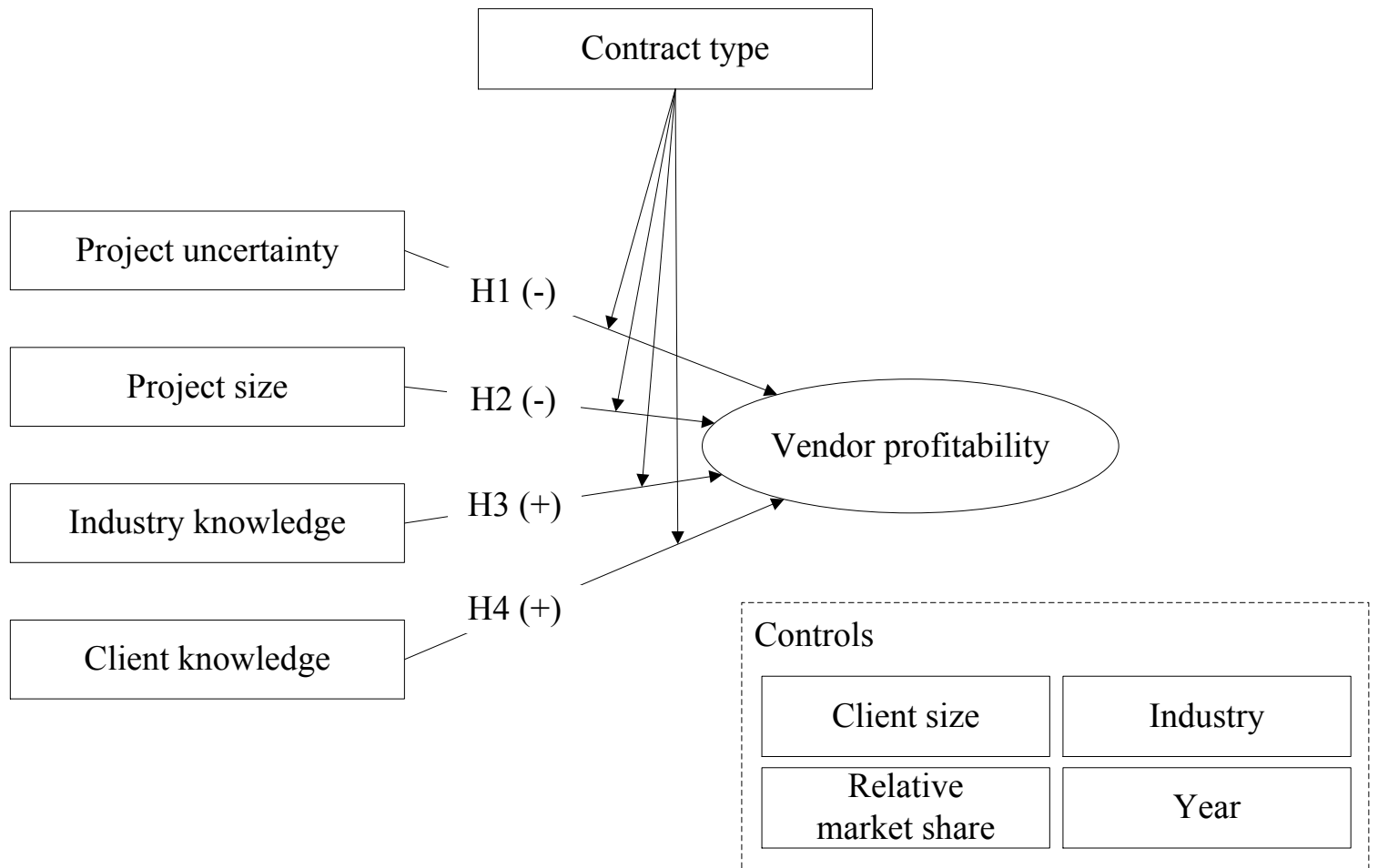

Figure 1. Research model 
Table 1.

Description of variables

\begin{tabular}{ll}
\hline Variable & Description and measurement \\
\hline Vendor profitability & $\begin{array}{l}\text { The share of project profits on project revenues multiplied by } 100 . \\
\text { Project uncertainty }\end{array}$ \\
$\begin{array}{l}\text { The absolute value of the share of actual project revenue on project budget } \\
\text { multiplied by } 100 .\end{array}$ \\
Project size & $\begin{array}{l}\text { Approximated using two proxies: a) the project budget in EUR and b) the project } \\
\text { duration between project start and project end in days. }\end{array}$ \\
Industry knowledge & The number of previous projects conducted by ALPHA within the same industry. \\
Client knowledge & $\begin{array}{l}\text { The number of previous projects conducted by ALPHA with the same client. } \\
\text { Client size }\end{array}$ \\
Relative market share & $\begin{array}{l}\text { ALPHA's revenues divided by the revenues of ALPHA's biggest competitor in a } \\
\text { given year. } \\
\text { The year in which the project was started. }\end{array}$ \\
Year & The SIC major group to which a client is assigned. \\
Industry &
\end{tabular}


Table 2. Descriptive statistics for fixed price (FP) and time and material (TM) contracts

\begin{tabular}{|c|c|c|c|c|c|}
\hline \multirow[b]{2}{*}{ Variable } & \multirow[b]{2}{*}{$\begin{array}{l}\text { Unit/ } \\
\text { Scale }\end{array}$} & \multicolumn{2}{|c|}{$\begin{array}{l}\text { FP sample } \\
(\mathrm{N}=3,400)\end{array}$} & \multicolumn{2}{|c|}{$\begin{array}{c}\text { TM sample } \\
(\mathrm{N}=30,508)\end{array}$} \\
\hline & & Mean & SD & Mean & SD \\
\hline Vendor profitability $^{1}$ & $\%$ & 47.34 & 21.02 & 36.54 & 12.28 \\
\hline Project uncertainty & $\%$ & 1.15 & 13.84 & 26.51 & 40.18 \\
\hline Project budget & ‘000 EUR & 84.50 & 367.65 & 58.04 & 280.92 \\
\hline Project duration & no. of days & 171 & 161 & 172 & 181 \\
\hline Industry knowledge & no. of projects & 1474 & 1385 & 1170 & 1328 \\
\hline Client knowledge & no. of projects & 143 & 224 & 86 & 145.25 \\
\hline Client size & no. of employees & 67,946 & 113,163 & 54,86 & 106,199 \\
\hline Relative market share & $\%$ & 31.11 & 1.42 & 31.38 & 1.23 \\
\hline
\end{tabular}

FP, fixed price contract; TM, time and material contract; SD, standard deviation; EUR, Euro; no, number

${ }^{1}$ For reasons of confidentiality we multiplied the values for the profit margin by a constant factor. 


\begin{tabular}{|c|c|c|c|c|}
\hline \multirow[b]{3}{*}{$\begin{array}{l}\text { Independent } \\
\text { variables }\end{array}$} & \multicolumn{4}{|c|}{ Dependent variable: Profit margin } \\
\hline & \multicolumn{2}{|c|}{$\begin{array}{c}\text { FP sample } \\
(\mathrm{N}=3,400)\end{array}$} & \multicolumn{2}{|c|}{$\begin{array}{c}\text { TM sample } \\
(\mathrm{N}=30,508)\end{array}$} \\
\hline & $\begin{array}{c}\text { OLS } \\
\text { coefficients }\end{array}$ & $\begin{array}{c}\text { Endogeneity- } \\
\text { corrected } \\
\text { coefficients }\end{array}$ & $\begin{array}{c}\text { OLS } \\
\text { coefficients }\end{array}$ & $\begin{array}{l}\text { Endogeneity- } \\
\text { corrected } \\
\text { coefficients }\end{array}$ \\
\hline Intercept & $\begin{array}{l}80.029 * \\
(32.005)\end{array}$ & $\begin{array}{c}532.098 * * * \\
(157.145)\end{array}$ & $\begin{array}{c}66.142 * * * \\
(9.124)\end{array}$ & $\begin{array}{c}66.274 * * * \\
(11.754)\end{array}$ \\
\hline $\ln ($ Project uncertainty +1$)$ & $\begin{array}{l}-1.221 \\
(1.131)\end{array}$ & $\begin{array}{l}-1.216 \\
(1.160)\end{array}$ & $\begin{array}{c}-0.412 * * * \\
(0.078)\end{array}$ & $\begin{array}{c}-0.411 * * * \\
(0.078)\end{array}$ \\
\hline $\ln ($ Project budget) & $\begin{array}{c}-3.642 * * * \\
(0.377)\end{array}$ & $\begin{array}{c}-1.513 \dagger \\
(0.781)\end{array}$ & $\begin{array}{c}-0.873 * * * \\
(0.117)\end{array}$ & $\begin{array}{c}-0.871 * * * \\
(0.175)\end{array}$ \\
\hline $\ln ($ Project duration) & $\begin{array}{c}3.021 * * * \\
(0.551)\end{array}$ & $\begin{array}{c}2.976^{* * * *} \\
(0.549)\end{array}$ & $\begin{array}{c}-0.715 * * * \\
(0.098)\end{array}$ & $\begin{array}{c}-0.715 * * * \\
(0.098)\end{array}$ \\
\hline $\ln ($ Industry knowledge +1$)$ & $\begin{array}{l}1.103 * \\
(0.505)\end{array}$ & $\begin{array}{c}2.313 * * * \\
(0.603)\end{array}$ & $\begin{array}{c}0.460 * * \\
(0.157)\end{array}$ & $\begin{array}{c}0.461 * * \\
(0.171)\end{array}$ \\
\hline $\ln ($ Client knowledge +1$)$ & $\begin{array}{l}-0.934 \\
(0.760)\end{array}$ & $\begin{array}{l}-1.711 \\
(0.832)\end{array}$ & $\begin{array}{c}-0.470 * * \\
(0.169)\end{array}$ & $\begin{array}{c}-0.470 * * \\
(0.179)\end{array}$ \\
\hline $\ln ($ Client size $)$ & $\begin{array}{l}-0.015 * \\
(0.007)\end{array}$ & $\begin{array}{c}0.004 \\
(0.010)\end{array}$ & $\begin{array}{l}-0.001 \\
(0.003)\end{array}$ & $\begin{array}{l}-0.001 \\
(0.003)\end{array}$ \\
\hline Relative market share & $\begin{array}{l}-2.044 * \\
(1.028)\end{array}$ & $\begin{array}{c}-11.335 * * * \\
(3.341)\end{array}$ & $\begin{array}{c}-0.974 * * * \\
(0.247)\end{array}$ & $\begin{array}{l}-0.985 \\
(0.633)\end{array}$ \\
\hline Year & $\mathrm{p}<0.01$ & $\mathrm{p}<0.01$ & $\mathrm{p}<0.01$ & $\mathrm{p}<0.01$ \\
\hline Industry & $\mathrm{p}<0.01$ & $\mathrm{p}<0.01$ & $\mathrm{p}<0.01$ & $\mathrm{p}<0.01$ \\
\hline$\lambda$ & - & $\begin{array}{c}-191.599 * * \\
(62.584)\end{array}$ & - & $\begin{array}{c}-0.293 \\
(15.072)\end{array}$ \\
\hline $\begin{array}{l}F \\
(\text { d.f. })\end{array}$ & $\begin{array}{c}20.39 * * * \\
(22 ; 3,377)\end{array}$ & $\begin{array}{l}19.94 * * * \\
(23 ; 3,376)\end{array}$ & $\begin{array}{c}91.48 * * * \\
(22 ; 30,485)\end{array}$ & $\begin{array}{c}87.5 * * * \\
(23 ; 30,484)\end{array}$ \\
\hline $\mathrm{R}^{2}$ (adj.) & $0.117(0.112)$ & $0.120(0.113)$ & $0.062(0.061)$ & $0.061(0.061)$ \\
\hline
\end{tabular}

FP, fixed price contract; TM, time and material contract; OLS, ordinary least squares

d.f., degrees of freedom; $* * *$, significant at the $0.1 \%$ level; **, significant at the $1 \%$ level; *, significant at the $5 \%$ level; $\uparrow$, significant at the $10 \%$ level. Clustered standard errors are shown in parentheses. 


\section{APPENDIX}

Table 4. Correlation matrix for the FP subsample $(N=3,400)$

\begin{tabular}{|c|c|c|c|c|c|c|}
\hline Variable & $\begin{array}{l}\text { Vendor } \\
\text { profitability }\end{array}$ & $\begin{array}{l}\text { Project } \\
\text { uncertainty }\end{array}$ & $\begin{array}{l}\text { Project } \\
\text { budget }\end{array}$ & $\begin{array}{l}\text { Project } \\
\text { duration }\end{array}$ & $\begin{array}{l}\text { Industry } \\
\text { knowledge }\end{array}$ & $\begin{array}{l}\text { Client } \\
\text { knowledge }\end{array}$ \\
\hline $\begin{array}{l}\text { Vendor } \\
\text { profitability }\end{array}$ & 1.00 & & & & & \\
\hline $\begin{array}{l}\text { Project } \\
\text { uncertainty }\end{array}$ & -0.02 & 1.00 & & & & \\
\hline $\begin{array}{l}\text { Project } \\
\text { budget }\end{array}$ & $-0.14 * * *$ & $0.04 *$ & 1.00 & & & \\
\hline $\begin{array}{l}\text { Project } \\
\text { duration }\end{array}$ & $-0.06 * * *$ & $0.06 * * *$ & $0.37 * * *$ & 1.00 & & \\
\hline $\begin{array}{l}\text { Industry } \\
\text { knowledge }\end{array}$ & 0.01 & -0.03 & $-0.06 * * *$ & $-0.09 * * *$ & 1.00 & \\
\hline $\begin{array}{l}\text { Client } \\
\text { knowledge }\end{array}$ & $-0.16^{* * *}$ & -0.01 & 0.02 & 0.02 & $0.20 * * *$ & 1.00 \\
\hline Table 5. & \multicolumn{6}{|c|}{ Correlation matrix for the TM subsample $(N=30,508)$} \\
\hline Variable & $\begin{array}{l}\text { Vendor } \\
\text { profitability }\end{array}$ & $\begin{array}{l}\text { Project } \\
\text { uncertainty }\end{array}$ & $\begin{array}{l}\text { Project } \\
\text { budget }\end{array}$ & $\begin{array}{l}\text { Project } \\
\text { duration }\end{array}$ & $\begin{array}{l}\text { Industry } \\
\text { knowledge }\end{array}$ & $\begin{array}{l}\text { Client } \\
\text { knowledge }\end{array}$ \\
\hline $\begin{array}{l}\text { Vendor } \\
\text { profitability }\end{array}$ & 1.00 & & & & & \\
\hline $\begin{array}{l}\text { Project } \\
\text { uncertainty }\end{array}$ & $-0.03 * * *$ & 1.00 & & & & \\
\hline $\begin{array}{l}\text { Project } \\
\text { budget }\end{array}$ & $-0.08 * * *$ & $-0.03 * * *$ & 1.00 & & & \\
\hline $\begin{array}{l}\text { Project } \\
\text { duration }\end{array}$ & $-0.13 * * *$ & $0.02 * * *$ & $0.24 * * *$ & 1.00 & & \\
\hline $\begin{array}{l}\text { Industry } \\
\text { knowledge }\end{array}$ & $0.09 * * *$ & $-0.04 * * *$ & $-0.03 * * *$ & $-0.07 * * *$ & 1.00 & \\
\hline $\begin{array}{l}\text { Client } \\
\text { knowledge }\end{array}$ & $-0.02 * * *$ & $-0.04 * * *$ & $0.02 * * *$ & $-0.01 *$ & $0.14 * * *$ & 1.00 \\
\hline
\end{tabular}




\begin{tabular}{|c|c|}
\hline & Dependent variable: Contract type \\
\hline $\begin{array}{l}\text { Independent } \\
\text { variables }\end{array}$ & $\begin{array}{c}\text { Probit } \\
\text { coefficients }\end{array}$ \\
\hline Intercept & $\begin{array}{c}32.258 * * * \\
(7.731)\end{array}$ \\
\hline $\ln$ (Project budget) & $\begin{array}{c}0.079 * * * \\
(0.006)\end{array}$ \\
\hline $\ln ($ Industry knowledge +1$)$ & $\begin{array}{c}0.052 * * * \\
(0.010)\end{array}$ \\
\hline $\ln ($ Client knowledge +1$)$ & $\begin{array}{c}-0.030 * * * \\
(0.008)\end{array}$ \\
\hline Client size & $\begin{array}{c}0.000 * * * \\
(0.000)\end{array}$ \\
\hline Relative market share & $\begin{array}{c}-1.087 * * * \\
(0.245)\end{array}$ \\
\hline Year & $\mathrm{p}<0.001$ \\
\hline Industry & $\mathrm{p}<0.001$ \\
\hline$N$ & 33,908 \\
\hline $\begin{array}{l}\text { Log-likelihood } \\
\text { (d.f.) }\end{array}$ & $\begin{array}{c}-10514.97 \\
(21)\end{array}$ \\
\hline $\begin{array}{l}\text { Chi-square } \\
\text { (d.f.) }\end{array}$ & $\begin{array}{c}1056.29 * * * \\
(21)\end{array}$ \\
\hline McFadden's pseudo R-squared & 0.046 \\
\hline
\end{tabular}

$\mathrm{FP}$, fixed price contract $=1 ; \mathrm{TM}$, time and material contract $=0$

d.f., degrees of freedom; $* * *$, significant at the $0.1 \%$ level; **, significant at the $1 \%$ level; *, significant at the $5 \%$ level; $\dagger$, significant at the $10 \%$ level. Standard errors are shown in parentheses. 


\section{BIOGRAPHIES}

Stefan Hoermann is a Ph.D. student at the Chair for Information Systems, Technische Universität München (TUM), Germany. He holds a diploma in Business Administration from TUM. Prior to writing his doctoral thesis he worked as a management consultant. Stefan's current research is aimed at improving risk management in ERP projects. He has presented his work at a variety of international conferences such as AMCIS, HICSS, ECIS, and ICIS.

Tobias Hlavka is a master student of Information Systems at Technische Universität München (TUM), Germany. He holds a Bachelor's degree in Information Systems from TUM. Tobias worked as a student research assistant at the Chair of Information Systems where he also wrote his bachelor's thesis on ERP project profitability. Tobias's current research interest is focused on the dynamics of risk management in ERP projects.

Michael Schermann is a postdoctoral researcher of Information Systems at the Chair of Information Systems, Technische Universität München (TUM), Germany. He holds a master's degree in Information Systems from Technische Universität Dresden and a doctoral degree in Information Systems from the Technische Universität München. His research interests include IT-enabled management control systems, risk management, and project management. His work has appeared in Journal of Management Accounting Research, Wirtschaftsinformatik, and conferences such as the International Conference on Information Systems (ICIS).

Helmut Krcmar is a full professor of Information Systems at Technische Universität München (TUM), Germany since 2002. He worked as a Post Doctoral Fellow at the IBM Los Angeles Scientific Center, as assistant professor of Information Systems at the Leonard Stern School of Business, NYU, and at Baruch College, CUNY. From 1987 to 2002 he was Chair for Information Systems, Hohenheim University, Stuttgart. His research interests include information and knowledge management, service management, business process management, and business information systems. His work has appeared in Journal of Management Information Systems, Wirtschaftsinformatik, Requirements Engineering, Information Systems Journal, International Journal of Medical Informatics, and conferences such as the International Conference on Information Systems (ICIS).

\footnotetext{
${ }^{\mathrm{i}}$ We thank an anonymous reviewer for pointing out the problem of inflation to us.
} 